\title{
COMPARATIVE ANALYSIS OF TAX SYSTEMS IN GERMANY AND SERBIA
}

\author{
Dragiša B. Veličković* \\ Singidunum University, Belgrade \\ Jelena M. Veličković**
}

Academy of Business Vocational Studies, Belgrade

\begin{abstract}
The tax systems in Serbia and Germany are based on the same principles and they consist of very similar types of taxes. Both of these tax systems are decentralised in accordance with state regulations. The tax system in Germany is more developed. It encompasses more tax types, it is more oriented towards environmental protection, more efficient in tax collection, and it is more consistent and fair regarding the burden of taxpayers in accordance with their tax power.
\end{abstract}

Key Words: tax, tax systems, tax burden, contributions

\section{Introduction}

Tax competitiveness is a part of an economic environment, which greatly influences the level of investment inflow and economic growth. Creators of the tax system, economic and development policy in Serbia, highlight the competitiveness of the tax system in Serbia because of its low rates of certain taxes. On the other hand, business circles complain about the high fiscal burden. The comparative analysis of the tax systems in Serbia and Germany, the countries with a regulated tax system, aims to help resolve this dilemma.

\section{Literature, methodology and goal}

The following comparative analysis has been conducted using the relevant constitutions and tax laws in Germany and Serbia, the tax system in Germany being in the forefront. Moreover, the analyses and findings of Seibert (The German Economy - Beyond the Social Market), Schubert, K. and Klein (Das Politiklexikon), Jochum (Introduction to German Tax Law) have been employed in the analysis, as they provide an analysis of the basis of the tax system in Germany. Raičević, B. and Ranđelović, S., 2008 analysed the tax rates in Serbia, and the labour taxation system has been analysed in NALED's research, which also provided recommendations for potential avenues for its reform.

\footnotetext{
*Dragiša B. Veličković, PhD, Full professor, dvelickovic@singidunum.ac.rs

** Jelena M. Veličković, PhD, Professor of vocational studies.
} 
German companies are one of the biggest investors in Serbia. This analysis aims to provide an answer to the question whether the tax system in Serbia is a factor, which contributes to the decision of German companies to invest in Serbia. What are the similarities, and what are the differences between the tax systems of these two countries? Are the similarities of tax systems and lower tax burden an advantage for Serbia when it comes to attracting German investment?

\section{Structure of the countries and tax systems}

Germany and Serbia have multiple differences. Germany (Bundesrepublik Deutschland) is the most populous country in European Union (82 million citizens, 42.65 million of work capable citizens), and it is one of the most developed countries in the world, with the strong industry and economy, which exports one third of its gross domestic product. On the other hand, Serbia has 7.3 million citizens, it is not a member of the EU, and it is still an underdeveloped country. According to the World Bank data ${ }^{1}$, Serbian GDP is 88.75 times lower than German. Gross domestic product (purchasing power parity) in 2017 was 105.5 billion $\$, 15,000 \$$ per capita, whilst in Germany it was 4.171 million $\$, 50,400 \$$ per capita, which puts Serbia on the 83rd and 112th place, and Germany on the 6th and 27 th place 2 .

Still, when it comes to the fiscal burden, these two countries are quite comparable. The fiscal burden in Germany is around the EU average and it is $44.5 \%{ }^{3}$, whilst in Serbia it is $39 \%{ }^{4}$, according to the Chamber of Commerce of Serbia, and it is thus around the average in the region.

Serbia and Germany also have different constitutions. While Serbia is a unitary state with two autonomous regions, Germany is a federal parliamentary republic with 16 constituent states. With the 1949 constitutional document, the authorities including the taxation authorities were separated into three levels: the federal government (Bund), the states (Länder), and the municipalities (Gemeinden).

The basis of German financial system lies within the constitutional principle of equal access to public goods and benefits. From this principle, the principles of equality in taxation and the lawfulness of taxation (Federal Constitutional Court (BVerGE) 49, 148, 98 and $3659)$ have emerged. The equality in taxation principle, or the payment capability principle, states that there are different tax burdens for different economic powers. The principle of the rule of law, or the lawfulness of taxation principle, entails the protection from the arbitrariness of the state and abuse of power by the authorities (Schubert, K., Klein, M., 2011., pp. 9). The fourth basic taxation principle stems from the welfare state, and it states that the income necessary for sustaining the minimal life standard should not be taxed, and that the income tax of citizens must not be over half of their income (Federal Constitutional Court (BVerGE) 93, 121). According to Siebert (Siebert, H., 2005, p. 18.), nearly one third of the gross domestic product in Germany relates to the so - called "social budget".

\footnotetext{
${ }^{1}$ http://databank.worldbank.org/data/download/GDP.pdf , 11.9.2018.

${ }^{2}$ https://www.cia.gov/library/publications/the-world-factbook/geos/gm.html , 3.9.18

${ }^{3} \mathrm{https}: / /$ data.oecd.org/gga/general-government-revenue.htm , 11.9.2018.

${ }^{4} \mathrm{https}: / /$ data.oecd.org/gga/general-government-revenue.htm , 11.9.2018.
} 


\section{Jurisdiction}

Customs, fiscal monopolies ${ }^{5}$ and law-making in whole or in part (Constitution, clause 105, paragraph 1-2) fall under the federal level. The constituent states have legislative competence related to the local taxes on consumption, local expenditures, and taxes which are essentially not similar to taxes regulated by the federal legislation (Constitution, clause 105, paragraph 2a). Municipalities do not have legislative power related to the taxation law. They have jurisdiction when it comes to the municipal multiplier for estimating the immovable property tax and the sales tax. The federal republic can adjust to the taxes which bring income to the federal state and municipalities (in part or in whole), with the permission from the Parliament (Constitution, clause 105, paragraph 3).

\section{Types of taxes}

In both countries, all three groups are represented: property taxes (in statics and dynamics), income taxes (citizens and corporations), and taxes on expenditures (consumption, fiscal monopolies and customs).

The Law on Budgetary System of Serbia involves public revenue (taxes on income, profits, property and transfer of property of natural and legal persons), social security contributions, taxes, and fees (Articles 14 and 15).

\section{Affiliation}

The tax systems of the two countries do not differ so much by the types of taxes, but they differ in their affiliation because the state structures are also different. In Germany, the federal level (Bund) includes the revenues from fiscal monopoly, income from customs duties, insurance taxes, capital transaction tax, one-time property tax and equalization of tax burden, tax on income for the citizen and corporate income tax, solidarity allowance and charges imposed within the EU. The constituent states have revenues from property tax, inheritance, motor vehicle tax, transactions that are not at federal level or do not belong together to the alliance and constituent states, e.g. VAT, beer, and casinos.

Revenues come from income tax on citizens, profits of companies and VAT of the federal republics and constituent states. The constituent states with higher incomes in the process of "horizontal equalization" are obliged to pay off part of the revenue for "equalization" to the constituent states with lower tax revenues (Constitution, Article 107, paragraph 2). Along with the horizontal, in the process of "vertical equalization", the Federal Republic pays additional funds to the constituent states if necessary.

\footnotetext{
${ }^{5}$ Fiscal monopoly - mostly state-owned enterprises, quasi-corporations and government-owned jobs that are legally monopolized.
} 
Municipalities are the part of the income tax on the income of the municipality's residents, the part of the VAT revenue, after the distribution between the federal level and constituent states (Constitution, Article 106, paragraphs 1, 2 and 5), income from immovable property tax, income from local taxes on consumption and remuneration, and the part of the income tax imposed by the constituent state to which the municipality belongs. According to the Constitutions of the Federal States it is an imperative to equalize the tax revenues of municipalities as support to the municipalities with lower (tax) revenues.

Unlike Serbia, the most expensive tax for municipalities is the tax on additional value. In Serbia, the Republic's budget includes VAT, excises, duties and taxes on using, holding and carrying certain goods. Local self-governments belong to property tax, inheritance tax, gift and transfer tax on absolute rights. A portion of corporate income tax belongs to the republic level, and the part of the corporation income tax is retained in the province. Income tax on citizens is divided into three levels depending on where it is collected.

\section{Taxes at the Federal Level}

\section{Excises}

Like in Serbia, the income from excise taxes is handled on the federal level in Germany. Serbia has regulated its excise system based on the EU member states one. However, there are also differences in the way in which the excise rates are determined, the products for which the excise is paid, as well as the levels of excise rates. In Germany, energy tax (electricity, coal, oil, petrol, kerosene, liquefied gas, natural gas, and lubricating oil) is paid in the form of excises. In addition to the energy products, excise products in Germany include tobacco, alcoholic beverages, and coffee. Excise on electricity is paid in the form of ecotax. It is collected from the supplier, and paid by the consumer (Law on Electricity Tax, Article 3). It is not paid for sustainable energy.

\section{Insurance tax}

Insurance tax is treated as transfer tax. The value of the insurance premium is taxed for immovable property, motor vehicles and travel insurance (Law on Insurance Tax Versicherungsteuergesetz, Article 1, paragraph 2). The tax rate is up to $19 \%$. In their entirety they belong to the federal level. Health insurance, life insurance, unemployment insurance, reinsurance, social security, etc. are not taxed (Versicherungsteuergesetz, Article 4). Fire protection tax (for fire insurance) belongs to the constituent states. The taxpayer is an insurance company, and the tax base is an insurance premium.

\section{Motor vehicles tax}

Until 2009, it was collected at the constituent state level, and now it is collected at the federal level. It is highly elaborate according to the vehicle categories. The amount of taxes is influenced by the emissions of harmful gases, noise, engine type, and its volume. 
Air travel tax

Air travel tax refers to each passenger flight embarked from any location in Germany and ranges from $€ 7.50$ to $€ 42.18$ depending on the destination.

\section{Solidarity tax}

The solidarity tax, introduced in 1991 to finance the cost of reunification of West and East Germany, is in fact a tax on taxes, so its survival is controversial. The solidarity rate is $5.5 \%$ of the income tax and corporate income tax. This burden also applies to the deduction tax. Both residents and non-residents are subject to payment (Jochum, H., 2013, p. 52).

\section{Taxes imposed by the constituent states}

The constituent states are responsible for inheritance and gift taxes. The inheritance (property) tax, gift and property of the foundation (Law on inheritance and gift tax, Article 19) are paid by natural and legal persons (Law on inheritance and gift tax, Article 2, paragraph 1). The tax rate, just like in Serbia, depends on the degree of kinship, the estimated value of inheritance or gifts, and, unlike in Serbia, the tax class (there are three of them) the recipient or the successor belongs to (Law on inheritance and gift tax, Article 19 , paragraph 1). Individuals are exempt from paying taxes at the rate that depends on the value of the inheritance or gift and the tax class they are assigned to.

Real estate tax

This type of tax is regulated in a very similar way in both countries. The real estate tax rate in Germany, unlike Serbia, is not the same in all federal states and ranges from 3.5\% in Bavaria and Saxony to $6.5 \%$ in North Rhine-Westphalia, Saarland, and Schleswig-Holstein.

\section{Betting and lottery tax}

The betting and lottery tax (horse racing and sports betting) is a federal tax and the income belongs to the federal states. The rate is $5 \%$, and the taxpayer is the betting organizer, while the tax base is the stake. For national lottery, the tax rate is $20 \%$ of the nominal stake value, while the tax rate for the foreign lottery is 0.25 euros for each invested euro within the nominal stake value. The taxpayer is a national lottery organizer, and in the case of a foreign lottery, the taxpayer is the individual who brings the lottery ticket into the territory of Germany.

\section{Church tax}

It is charged by the tax authorities and the income belongs to religious communities. The taxpayers are the members of religious communities that are in the register. These taxes (about nine billion euros a year) make up about $70 \%$ of the income of religious 
communities. These communities can also collect this tax by themselves. The rate is $8 \%$ in Bavaria and Baden-Württemberg and $9 \%$ in other countries (Jochum, H., 2013, p. 41). The tax base is the income tax for citizens.

\section{Beer tax}

The revenue from this tax belongs to the constituent states, which are also responsible for regulating it.

\section{Taxes at the Municipal Level}

\section{Commercial activity and entrepreneurs' tax}

It should not be confused with the corporate income tax, which is in Germany paid by larger companies with a higher income. The tax rate consists of a base rate $(3.5 \%)$ and a municipal multiplier. Depending on the municipality, the rates range from $7 \%$ to $17 \%$.

The taxable tax base is obtained by multiplying the taxable income with the base tax rate of $3.5 \%$ and the final amount by multiplying the base with the corresponding municipal multiplier (350-400\%, and never less than 200\%) (Gewerbesteuergesetz (GewStG), Article 16). There is no upper limit for the size of the multiplier and it is generally higher in urban than in rural areas. Currently, it does not exceed $490 \%$ in any major city.

Partnership companies are exempt from tax in the amount of up to 24,500 euros. For this tax a solidarity burden ${ }^{6}$ is not charged, unlike for the tax on income of citizens and the corporate income tax.

\section{Tax on real estate}

Like in Serbia, the taxpayer is the owner of the real estate, and the tax base is its value. Taxation is performed in the same way as with the tax on commercial activity and entrepreneurs because there is also a municipal multiplier.

\section{Taxes on dogs and horses}

These taxes are treated as property taxes and are paid by the owners of dogs and horses annually. The amount is not the same in all municipalities. It is not paid for dogs that help people with disabilities. In some countries, the hunting tax is paid. Serbian tax system does not include this tax.

\section{Entertainment tax}

It is paid for the entry price for individual events (tax on tickets), slot machines, game machines, and video game machines. Berlin, Hamburg, Bremen, Bavaria, and Saarland are municipalities that do not have a regulated tax on entertainment.

\footnotetext{
${ }^{6}$ http://www.nrwinvest.com/Business_Guide_englisch/The_tax_system/Company_Taxation1/index.php (24.08.2018.)
} 
The objects of taxation are also the game machines that are paid for, regardless of whether there is a possibility of winning. The tax base depends on the number of devices, token sales, etc., or the lump sum. The tax rate is $10 \%-13 \%$ on the amount of turnover represented by the tax base, regardless of the number and location of the machines.

\section{Tax on sexual services}

The legalization of prostitution has also introduced a tax on sexual services. The taxes for clubs and bars amount to three euros per $10 \mathrm{~m} 2$ area, and for prostitution is six euros per service.

\section{Taxes divided into three levels}

\section{Income tax on citizens (I natural persons)}

In Germany, a synthetic income tax system is applied, which takes into account numerous personal circumstances of the taxpayer. In addition to the general non-taxable minimum, there is also a very well-developed set of tax incentives, standard and nonstandard deductions to reduce the tax base or calculate the tax.

Employees pay income tax that is treated as a tax on deduction (tax on the source). Taxpayers who only make revenue which is subject to a deduction tax are exempt from the general obligation to submit tax returns. However, the taxpayers (also applies to married couples) have the right to file a tax claim because some of them may be entitled to a deduction and a tax refund.

The taxpayers are residents (Income Tax Law, Article 1). The revenue from agriculture and forestry, business ventures, self-employment, employment, i.e. employment with an employer, capital, and renting assets is recognized (Income Tax Law, Article 2, paragraph 1). Some income (Income Tax Law, Article 3, paragraph 1-3) is not taxed. The taxpayers are divided into six tax groups (Income Tax Law, Article 38b, paragraph 1-6). The tax rate is progressive and ranges from $0 \%$ to $45 \%$. The amounts up to 8,354 euros for singles and up to $16,708^{8}$ euros for married couples are not taxed. The basic tax rate is $14 \%$, and grows with income up to $45 \%$ for taxable income of $€ 250,731$, i.e. $€$ 501,462 for married couples. The tax base can be deducted based on the defined costs ${ }^{9}$.

Non-residents in Germany may be in a limited or full tax liability, depending on their income. Limited tax liability refers to the income from employment by an employer, capital property, rental, private disposal of parcels in the territory of Germany. Tax rates for nonresidents are the same as for residents, and some deductions are also implemented.

\footnotetext{
${ }^{7}$ http://www.bremische-buergerschaft.de/drs_abo/Drs-17-966_404.pdf (24.09.2018.)

${ }^{8}$ Couples can report their income together and be taxed at a more favorable tax rate.

${ }^{9}$ Savings costs: insurance premiums, additional retirement savings, donations, extraordinary financial burdens (costs in case of illness, for example), cost of professional training, non-taxable child allowance, and childcare allowance, educational or professional treatment of the child.
} 
Serbia applies a mixed system, cedular taxation being dominant. As in Germany, there is a special rate for each type of income of a natural person subject to taxation. Except for the annual income tax, rates are proportional and range from $10 \%$ for the revenue from independent operations to $20 \%$ for capital gains. The effective rate, calculated on the basis of average earnings, is $10.45 \%$ (Raičević, B., Ranđelović, S., 2008, page 4).

The income tax on citizens' base in Serbia is significantly lower than in Germany. Germany has a highly developed system of standard and non-standard deductions (personal exemption, for dependent persons, housing issues, education and training, treatment and rehabilitation, etc.). In Serbia, that is not the case. There is only a non-taxable minimum (15,000 dinars for earnings tax) and two standard deductions for annual income tax, personal exemption at the rate of $40 \%$ of taxpayer's average earnings and $15 \%$ of the annual average earnings for each dependent family member. The total deduction cannot exceed $50 \%$ of the taxable income.

The annual income tax on citizens is paid by residents whose annual income is higher than the average annual income - three times higher (for resident aliens - five times) and six times higher (for resident aliens - eight times). The rates are progressive and they range from $10 \%$ to $15 \%$. The non-taxable amount is fairly high, so a relatively small number of people are affected by this tax.

The exemption from the income tax and contributions for compulsory social security at the expense of the employer is allowed for certain categories of newly-employed persons over a period of three years.

\section{Capital gains tax}

The capital gains tax is a type of income tax on citizens and corporate income tax. The income from capital assets is taxed at the rate of $25 \%$ (plus a solidarity burden of $5.5 \%$ ) in Germany and in Serbia at the rate of $15 \%$.

\section{Taxation of partnership companies}

Partnership companies in Germany, companies with partners as entities, do not pay income tax, but each entity pays the income tax at the rate applicable to the income tax for residents.

\section{Dividend income tax (capital assets)}

In Germany, dividends are taxed at the rate of $25 \%$ (plus a solidarity burden of $5.5 \%$ ). When dividends are paid to companies with a full tax liability, they are almost completely exempt from paying taxes.

\footnotetext{
${ }^{10} \mathrm{http}: / /$ www.steuerliches-info-center.de/ (visited on: 25.08.2018.)
} 


\section{Social Security Contributions}

Compulsory social security contributions have a significant impact on the level of fiscal burden because they have a high share in the total public revenue. Obligations and structures of the social security systems in Germany and Serbia are identical. In both countries, one part of the contribution is paid by the employer, and the other part is at the expense of the employee. The employer calculates, suspends, and pays the total amount of contributions. In both countries, the basis for calculating contributions for compulsory social security is the gross earning of the employee.

Table 1 - Social contributions and the percentage paid by the employer and employee in Germany ${ }^{11}$

\begin{tabular}{|c|c|c|c|}
\hline Insurance policy & Annual amount & Employer & Employee \\
\hline Retirement insurance & $\begin{array}{l}\text { West } 72,600 € \\
\text { East } 62,400 €\end{array}$ & $9.35 \%$ & $9.35 \%$ \\
\hline $\begin{array}{l}\text { Unemployment } \\
\text { insurance }\end{array}$ & $\begin{array}{l}\text { West } 72,600 € \\
\text { East } 62,400 €\end{array}$ & $1.5 \%$ & $1.5 \%$ \\
\hline Care & $49,500 €$ & $1.175 \%$ & $1.175 \%-1.425 \%$ \\
\hline Health insurance & $49,500 €$ & $7.3 \%$ & $7.3 \%$ \\
\hline $\begin{array}{l}\text { Additional contribution } \\
\text { of an employee de- } \\
\text { pending on the insur- } \\
\text { ance company }\end{array}$ & 7 & 1 & $0.9 \%$ \\
\hline
\end{tabular}

Source: http://www.lohnsteuer.de/

Tax and social security contributions rates in the Republic of Serbia are as following ${ }^{12}$ :

1) Pension and disability insurance $-12 \%$ at the expense of the employer and $14 \%$ at the expense of the employee;

2) Health insurance $-5.15 \%$ at the expense of the employer and $15 \%$ at the expense of the employee and

3) Unemployment insurance $-0.75 \%$ at the expense of the employer and $0.75 \%$ at the expense of the employee.

Given that the average earnings in Serbia are substantially lower than in Germany, where taxation is progressive, the burden on earnings in Serbia is lower and probably at the level of the EU average. The total tax labour burden, or the so-called "tax wedge" in Serbia is $39.2 \%$, and in Germany $49.8 \%{ }^{13}$.

\section{Corporate Income Tax}

Corporate income taxpayer in Germany is the business society, a resident who performs a business activity in the country. In both countries, a legal entity which is registered (founded) or has the headquarters and/or place of actual administration and control

\footnotetext{
${ }^{11} \mathrm{http}: / / \mathrm{www}$. lohnsteuer.de/

${ }^{12} \mathrm{http}: / /$ www.croso.gov.rs/cir/Statistika/Stope_doprinosa/ (18.09.2018.)

${ }^{13} \mathrm{http}: / /$ uzmiracun.rs/htdocs/Files/00458/NALED_Sistem-oporezivanja-rada-i-moguci-pravci-njegove-reforme.pdf
} 
in the territory of the observed state, is considered a resident. In Serbia, the taxpayers are all legal entities, whereas in Germany they are bigger business societies. The socalled 'companies with limited liability' (Gesellschaft mit beschränkter Haftung or GmbH) or joint-stock companies (Aktiengesellschaft or AG) with headquarters or administration in Germany are subject to this tax with full tax liability. Their dividends, both generated and taxed or paid abroad, may be exempt. Companies that do not have headquarters or administration in the country (dual, i.e. double residents), established abroad, are subject to German unlimited tax liability if the legal character of the company is similar to the German type of company and its management in Germany. There are limitations in the case of group taxation of dual residents who hold companies.

Corporate income taxpayers are also non-residents when it comes to income made in the territory of the country in which they are non-residents. Between Germany and Serbia there are no systemic differences in defining the tax base and the tax base does not affect the differences in the level of the fiscal burden. The German rates are: general (upper) $38.7 \%$, special $40 \%, 30 \%$, and in Serbia it is $15 \%$. Taxable profit is determined on the basis of the final account (balance sheet and success balance). In Germany, a solidarity tax of $5.5 \%$ is charged for this tax, as well (Jochum, H., 2013, p. 43).

\section{Value-Added Tax}

VAT is to a great extent harmonised at the EU level. The principles which this type of tax should be based on have been established with the EU Sixth VAT Directive, and they have been incorporated into the legislations of both the EU members and Serbia. Therefore, there are no significant differences when it comes to this part of the tax systems of Serbia and Germany.

Table 2 - Short comparative display of important tax rates of Germany and Serbia

\begin{tabular}{|l|l|l|}
\hline \multicolumn{1}{|c|}{ Tax } & \multicolumn{1}{|c|}{ Germany } & \multicolumn{1}{c|}{ Republic of Serbia } \\
\hline Income tax on citizens & $\begin{array}{l}\text { from 0 to 45\% with a standard rate of } \\
14 \% ; \text { depends on the income and the tax } \\
\text { class of the taxpayer }\end{array}$ & $10 \%-15 \%$ \\
\hline Value-added tax & $\begin{array}{l}\text { general rate } 19 \% \\
\text { lower rate } 7 \%\end{array}$ & $\begin{array}{l}\text { general rate } 20 \% \\
\text { lower rate } 10 \%\end{array}$ \\
\hline Corporate income tax & $\begin{array}{l}15 \%+\text { solidarity tax at the rate of } 5.5 \%= \\
15.825 \%\end{array}$ & $15 \%$ \\
\hline Capital gains income & $25 \%+$ solidarity tax at the rate of $5.5 \%$ & $15 \%$ \\
\hline Dividend income & $25 \%+$ solidarity tax at the rate of $5.5 \%$ & $15 \%$ \\
\hline Inheritance and gift tax & $\begin{array}{l}\text { from 7\% to } 50 \% \text { depending on the income } \\
\text { and the tax class of the taxpayer }\end{array}$ & $1.5 \%$ to $2.5 \%$ \\
\hline Motor vehicle tax & $\begin{array}{l}\text { According to the emission class and en- } \\
\text { gine volume; the lower the emission class, } \\
\text { the lower the cost }\end{array}$ & $\begin{array}{l}\text { volume and engine } \\
\text { power }\end{array}$ \\
\hline
\end{tabular}

Source: processing of the author 


\section{Conclusion}

Taken globally, the tax systems of Serbia and Germany are very similar. One can draw this conclusion based on the existing types of taxes. Nevertheless, the tax system in Germany is much more elaborate, as it contains the types of taxes which do not exist in Serbia. Dog tax and horse tax, for example, do not exist in Serbia. There are a few unusual types of taxes including prostitution tax (as part of the entertainment tax) and church tax.

German tax system is structured in a manner that supports environmental protection. Motor vehicles tax, for example, is regulated so that citizens are encouraged to use the so-called "eco-friendly" and electric vehicles. Similarly, the excise on electricity is not paid if it is derived from sustainable sources.

The ability-to-pay principle is being implemented much more consistently in Germany. Tax burden on small entrepreneurs and businesses is lower than the burden on large companies which, unlike the former, pay the profit tax. In Serbia, this tax applies to all legal entities.

The same goes for the income taxation of natural persons. The advantage of this type of taxation in Germany are tax brackets, which support families and young married couples with lower tax rates and tax incentives. On the other hand, there are also very high tax rates (up to $45 \%$ ) for the highest earnings. This is, aside from the inheritance tax and a gift tax of $50 \%$ for the third tax class, one of the highest tax rates.

In Serbia, the cedular system with a very modest correction for synthetic income taxation in the form of annual taxes remains. With mostly proportional nominal tax rates $(10 \%$ to $20 \%)$, Serbia is one of the countries with lower tax burdens. There is no vertical equity of taxation, which is achieved by progressive taxation.

The total tax burden on labour in Serbia is lower than in Germany. Moreover, tax rates are generally lower in Serbia than in Germany. One could conclude that the level of fiscal burden is significantly lower, but that is not the case because of the share of grey economy, which in Serbia constitutes $30.1 \%$, whilst in Germany it constitutes only $12.2 \%$, i.e. it is around the average for the OECD countries.

Unlike Serbia, Germany has a very effective tax system and a high rate of tax collection. Furthermore, the fair distribution of tax revenues has been established in Germany.

\section{Literature}

[1] Brimerhof, D., (2009), Javne fnancije, 7. izdanje, prevod, MATE d.o.o, Zagreb.

[2] Jochum, H., (2013), Introduction to German Tax Law, Boorberg, Sttutgart.

[3] Raičević, B., Ranđelović, S., (2008), Analiza visine poreza u Srbiji, Industrija br. 1.

[4] Rakonjac-Antić Tatjana, (2012), Penzijsko i zdravstveno osiguranje, Ekonomski fakultet, Beograd.

[5] Schubert, K., Klein, M. (2011), Das Politiklexikon, 5. izdanje, Dietz, Bon.

[6] Siebert, H., (2005), The German Economy - Beyond the social market, Princeton University Press, Princeton.

Legislation in Germany

[1] Constitution (Grundgesetz)

[2] Law on the Budget System 
[3] Tax Duty Act (Tabaksteuergesetz)

[4] Law on motor vehicle tax

[5] Law on tax on anti-fire protection

[6] Tax Act on Commercial Activity

[7] Law on Immovable Property Tax

[8] Income Tax Law

[9] Law on Electricity Tax

[10] The Insurance Tax Act (Versicherungsteuergesetz)

[11] Law on inheritance and gift tax

[12] The Law on Income Tax

[13] Customs Law

\section{Legislation in Serbia}

[1] Constitution

[2] Law on Property Taxes

[3] Law on Income Tax on Citizens

[4] Law on Profit Tax on Legal Entities

[5] Customs Law

[6] Excise Law

[7] Law on Financing Local Self-Government

[8] The duo law

[9] Value Added Tax Act

[11] Law on Pension and Disability Insurance

[11] Employment and unemployment insurance Act

[12] Law on Health Care

[13] Law on Compulsory Social Security Contributions

[14] Health Insurance Act

EU legislation

[1] Commission Directive 2001/116/EC

[2] Directive 2002/24/EC 